Materiales de Construcción

Vol. 69, Issue 334, April-June 2019, e187

ISSN-L: 0465-2746

https://doi.org/10.3989/mc.2019.04618

\title{
Mechanical properties of some building stones from volcanic deposits of mount Erciyes (Turkey)
}

\author{
S. Yüksek $\triangle$ \\ Sivas Cumhuriyet University, Engineering Faculty, Mining Engineering Department, (Sivas, Turkey) \\ \syuksek@cumhuriyet.edu.tr
}

Received 4 May 2018

Accepted 6 November 2018

Available on line 20 March 2019

\begin{abstract}
Mount Erciyes is a huge stratovolcano of the Central Anatolian province in Turkey and it has produced calc-alkaline and pyroclastic rocks, which have been widely used as dimension stone in low-storied buildings and especially in historical monuments in the past. In the region there are some 205 quarries extracting volcanic rocks. In this study, the locations of these quarries and information on their annual stone production are evaluated. In order to assess the material properties of the Mount Erciyes volcanic products, petrographic analyses and a number of rock mechanical tests were carried out. Significant correlations were found between the properties of the rock samples. In particular, there is a significant relationship between thermal conductivity and some non-destructive measurement values such as P-wave velocity, Equotip and Schmidt hardness, and it is clear from the regression equations that these tests can be used as indicators for evaluating the Mount Erciyes products.
\end{abstract}

KEYWORDS: Mechanical properties; Petrography; Compressive strength; Modulus of elasticity; Thermal analysis

Citation/Citar como: Yüksek, S. (2019) Mechanical properties of some building stones from volcanic deposits of mount Erciyes (Turkey). Mater. Construcc. 69 [334], e187 https://doi.org/10.3989/mc.2019.04618

RESUMEN: Propiedades mecánicas de algunas piedras de construcción de depósitos volcánicos de monte Erciyes (Turquía). El Monte Erciyes es un enorme estratovolcán de la provincia central de Anatolia en Turquía y ha producido rocas calcalcalinas y piroclásticas, que han sido ampliamente utilizadas como piedra de dimensión en edificios de pisos bajos y especialmente en monumentos históricos en el pasado. En la región hay unas 205 canteras que extraen rocas volcánicas. En este estudio, se evalúan las ubicaciones de estas canteras y la información sobre su producción anual de piedra. Con el fin de evaluar las propiedades materiales de los productos volcánicos del Monte Erciyes, se llevaron a cabo análisis petrográficos y una serie de ensayos mecánicos de roca. Se encontraron correlaciones significativas entre las propiedades de las muestras de roca. En particular, existe una relación significativa entre la conductividad térmica y algunos valores de medición no destructivos, como la velocidad de la onda P, la dureza de Equotip y Schmidt, y se desprende de las ecuaciones de regresión que estas pruebas se pueden usar como indicadores para evaluar los productos de la montaña Erciyes.

PALABRAS CLAVE: Propiedades mecánicas; Petrografía; Resistencia a la compresión; Módulo de elasticidad, Análisis térmico.

ORCID ID: S. Yüksek (https://orcid.org/0000-0002-8960-6484)

Copyright: (C) 2019 CSIC. This is an open-access article distributed under the terms of the Creative Commons Attribution 4.0 International (CC BY 4.0) License. 


\section{INTRODUCTION}

Stones with different names such as dimension stones, engineered stones, natural stones and construction or building stones are the main materials of the building industry. Stones have been widely used both in buildings and open/closed public areas, particularly in tourist sites. The foundations and walls of constructions, external coverings, garden walls, park and garden arrangements, pavements, roads and pedestrian lane paving, the restoration of historical buildings, churches, mosques and minarets or landscape architecture, water spouts or gutter stones are typical examples. In order to use the stones in the aforementioned areas, their physical and mechanical properties should be determined by in-situ and/or laboratory tests (1). The two most important criteria in assessing natural stones as building materials are both their technical or material properties such as density, porosity, hardness, compressive and flexural strength, thermal conductivity etc., and the demand for the stone type (2). At the same time, the durability of building stones is crucial in the assessment. The durability of natural stones used as building materials decreases over time on account of weathering in terms of physical disintegration such as frost action, insolation, salt crystallization, plant root action, fire etc., or chemical decomposition such as dissolution of carbonates and sulfates, solubilization by leaching of elements from silicates and sulfides, followed by oxidation and hydration. In addition, the durability of a stone depends heavily on both its strength and pore structure properties. Benavente et al. (3) have put forward a strong correlation between salt weathering and a petro-physical durability estimator which is defined as the ratio of pore structure to material strength. On the other hand, factors defining the quality of a natural stone deposit are geological, such as appearance (colour, homogeneity, structure, fabric etc.), discontinuities (faults, joints and joints spacing, fissures and fillings etc.), mineralogical composition, resource type and reserve of the deposit. Both geological and non-geological factors are also crucial in assessing the building stones.

Another subject is the application of nondestructive measurements to determine the durability of the stones. Some authors have attempted to establish the relationship between rock durability and some non-destructive measurements such as ultrasound velocity, Schmidt hammer, Equotip and Shore hardness etc. (4-9). This study also revealed significant relationships between the material properties of rock samples.

The following information has been compiled for general information on the stone materials used in the experiments for this study. Construction material deposits of volcanic origin are widespread all over Turkey. The Central Anatolian Volcanic Province
(CAVP) and Eastern Anatolian Volcanic Province (EAVP) are the main volcanic areas of Turkey and they have numerous stratovolcanoes. Mount Erciyes, with an elevation of $3917 \mathrm{~m}$, is the largest stratovolcano mountain $\left(3300 \mathrm{~km}^{2}\right)$ of the CAVP, with a basal diameter of $55-60 \mathrm{~km}(10)$. It is situated about $15 \mathrm{~km}$ south of Kayseri city and its materials are distributed over large areas $\left(\sim 30,000 \mathrm{~km}^{2}\right)$. The first explosive activity is the ignimbrite eruption, $2.8 \mathrm{Ma}$ age- Pleistocene (11) and the last eruption dated 0,083 Ma- Holocene (12). Mount Erciyes and its volcanic groups have produced calc-alkaline and pyroclastic materials such as basalt, andesite, tuff, lavas, ignimbrite, dacite, rhyodacite and pumice. The thickness of these rocks, which constitute the whole Cappadocia region comprising Nevşehir, Kayseri, Aksaray and Niğde provinces of Central Anatolia, varies from one to several hundred meters. There are detailed studies on petrogenesis, geochemistry and mineral diversity of Hasandağ and Erciyes stratovolcano products $(13,14)$. A great many studies, most of which were on the durability of Cappadocia region volcanic rocks, have been carried out on tuffs and basalt stones related to Mount Erciyes (15-18). Moreover, some studies focused on the extraction and usability of basalts and tuffs of Mount Erciyes as construction materials (19-24). Apart from former studies in this study, some non-destructive methods such as ultrasonic velocity and Equotip hardness and some mechanical properties were investigated. In particular, it has been tried to establish meaningful relationships between these non-destructive measurements and thermal conductivity.

\section{BUILDING STONES RELATED TO MOUNT ERCIYES}

Volcanic quarry mining and thus the number of quarries are increasing on a yearly basis in Cappadocia region. Diamond wire cutting methods have been applied in quarries because of the ease in cuttability and workability of the volcanic rocks. Although the building stones in the region have the same origin and are called tuffs, their textures, colour and appearances are different and they are being marketed under different brand names and prices. The geotechnical and mineralogical properties of the stones vary among quarries, even within quarry regions. This fact makes it necessary to examine and evaluate every quarry individually.

The products of Mount Erciyes, different coloured tuffs and basalts, have been widely used as construction material in low-storied buildings, especially in historical monuments in the past. Nowadays, however, andesite, basalt, ignimbrites and different coloured tuffs are used for decorative purposes and paving. Additionally, basalts are used as pavement, concrete and road construction aggregate. The other rocks of Mount Erciyes are pumice 
and perlite, which are used in lightweight bricks and concrete. In Cappadocia volcanic province there are some 205 stone quarries, of which 109 are located in Kayseri province. According to data from the Turkish Republic's Ministry of Energy and Natural Resources-General Directorates of Mining Affairs, ca.1875390 tons of volcanic originated stone were mined from these regions in 2013. These production figures are estimated to have doubled at the present time and this provides a significant contribution to the Turkish economy.

\section{MATERIALS AND METHODS}

The volcanic rocks to be tested in our laboratory were taken from six different quarries in Kayseri province representing the stones sold commercially. Fresh blocks of olivine basalt (BVI) rock were taken from the İncesu region; blocks of grey ash tuff (TI), white ash tuff (TII) and pink ash tuff (TIII) rock were taken from Melikgazi-Gesi district; and blocks of yellow ash tuff (TIV) and brown ash tuff (TV) rock were taken from Tomarza region. The places where these samples were taken and the geological map of Mount Erciyes and its vicinity are given in Figure 1. Thin sections were prepared to determine the mineral composition and petrographic description of the samples. After petrographic definition of the stones gathered from the quarries, rock mechanical properties were determined.

For rock mechanics tests, as the tuffs and basalts do not show distinct layering, cores were extracted from the blocks in the vertical direction, which were expected to represent the material characteristics of the unit. Laboratory tests were conducted on NX-size cores (Ø $54.7 \mathrm{~mm})$. The cores had a lengthto-diameter ratio of 2.0-2.5. Tests were carried out in accordance with procedures laid out in the ISRM Suggested Methods (25) and Turkish Standards (26). Tests performed on the samples included dry and saturated unit weight in $\mathrm{kN} / \mathrm{m}^{3}$, porosity in $\%$, water absorption by weight in $\%$, P-wave velocitydry and saturated in $\mathrm{m} / \mathrm{s}$, coefficient of thermal conductivity $(\mathrm{k})$ in $\mathrm{W} / \mathrm{mK}$, flexural strength and uniaxial compressive strength (UCS) in MPa.

The porosity and water absorption of the rock samples were determined with the saturation technique, as recommended by TSE and ISRM standards. All specimens were saturated by water immersion for a period of $48 \mathrm{~h}$ with periodic agitation to remove trapped air. Then the specimens were inserted in a basket into an immersion bath and their saturated-submerged mass was measured with a scale having $0.01 \mathrm{~g}$ accuracy. Later, the surface of the specimens was dried with a moist cloth and their saturated-surface-dry mass was measured outside the water. The dry mass of the samples was determined after oven drying at a temperature of $105^{\circ} \mathrm{C}$ for a period of at least $24 \mathrm{~h}$. The absorption of the samples was calculated by dividing the difference in the saturated and dry mass of the specimens.

Wetting and drying tests were conducted on the tuff and basalt specimens. Five core samples of each rock unit were immersed for $24 \mathrm{~h}$ in distilled water at $20{ }^{\circ} \mathrm{C}$. The samples were dried in an oven at $105^{\circ} \mathrm{C}$ and then cooled to room temperature. This test was repeated 80 times and the wetting-drying loss was estimated for each rock sample.

In slake and durability tests, ISRM (25) and ASTM (27) standard procedures were followed. Rock lumps (10 pieces of about 40-60 g each) were prepared and rotated for $10 \mathrm{~min}$ in a test drum made of a standard sieve mesh so that the products of slaking were finer than $2 \mathrm{~mm}$ and could pass through the drum into the water bath. The drum was immersed in a slaking solution bath at $20{ }^{\circ} \mathrm{C}$. The slake durability index (Id) corresponding to each cycle was calculated as the percentage ratio of final to initial dry mass of rock in the drum after the drying and wetting cycles.

The coefficient of thermal conductivity values was obtained in our laboratory steady-state test apparatus, designed and produced in the Mining Engineering Department of Cumhuriyet University. The tests were carried out in the $100{ }^{\circ} \mathrm{C}(373 \mathrm{~K})$ temperature range of this apparatus. Three core specimens with a diameter of $54 \mathrm{~mm}$ and a length of $40 \mathrm{~mm}$ were prepared for each of the rock samples.

Uniaxial compressive strength (UCS) tests were performed on the NX-size $(54 \mathrm{~mm})$ core specimens. Core samples were kept in a temperature-controlled furnace at an ambient temperature of $70 \pm 5{ }^{\circ} \mathrm{C}$ until each one reached a constant mass, followed by the natural cooling of the specimens to room temperature. UCS values were calculated by dividing the maximum failure load by the section area of the specimen. The tests were repeated at least five times for each rock type and the mean value was recorded as the UCS.

Flexural strength or three-point bending tests were conducted according to TS (26) standard on core samples with a length of $125 \mathrm{~mm}$. The load at failure was used to calculate the flexural strength of the rocks. Five core samples from each rock tested were used and the average value was obtained as the flexural strength.

The point load strength test involves loading core specimens or irregular rock fragments between the conical platens and measuring the applied force $(\mathrm{P})$ and the distance (D) between the platens at failure. In this test, the ISRM (25) standard procedures were followed. For each rock type, five NX-size core samples with a length-to-diameter ratio of 1 were prepared and the samples were subjected to the test. The point load strength index $I_{s}$ was calculated and corrected to the $50 \mathrm{~mm}$ standard core diameter.

The commonly used ultrasonic parameter in material strength determination is the $\mathrm{P}$-wave 


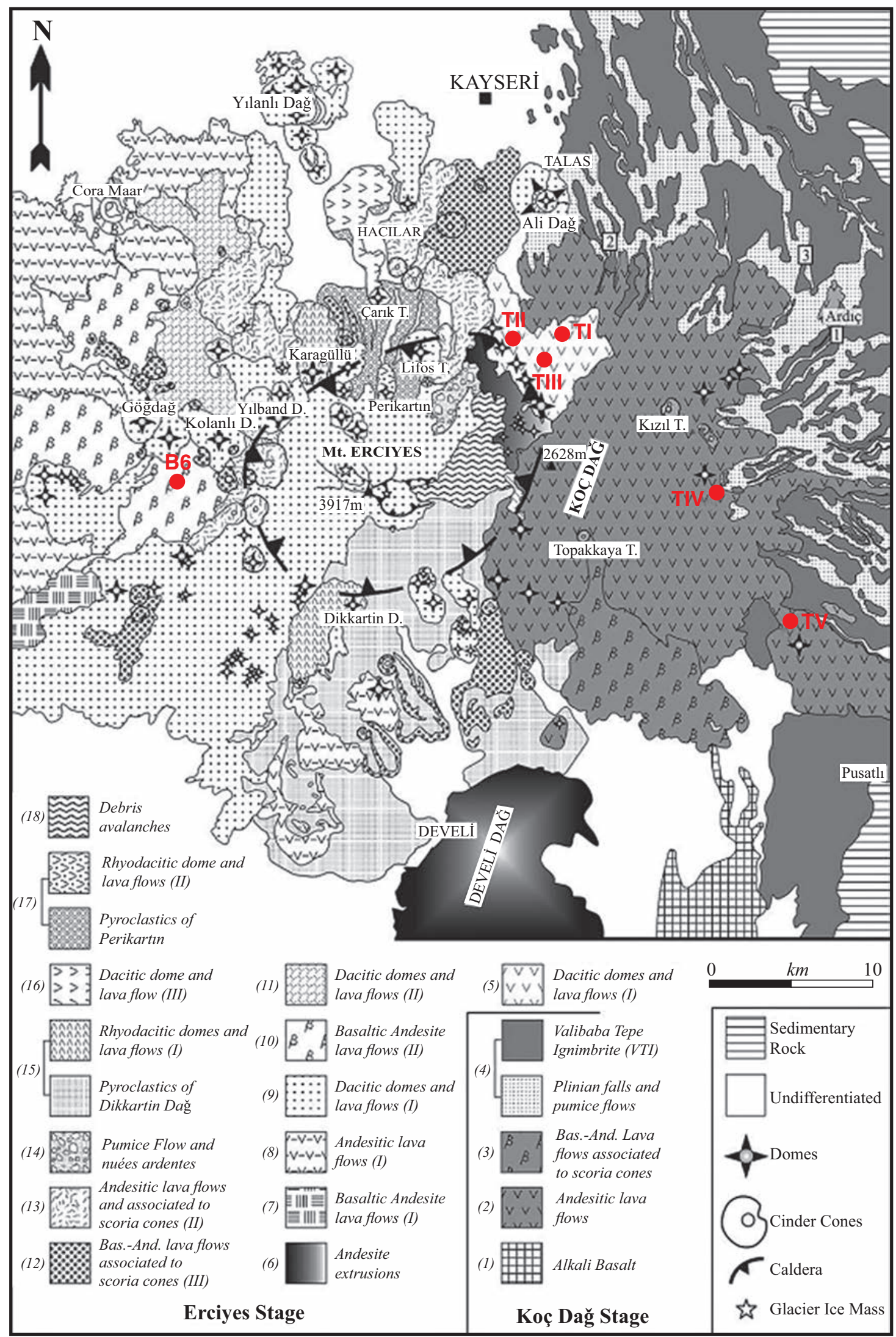

FIgURE 1. Geological map of Mount Erciyes and the vicinity (10). (The red circles show the quarries where the samples were taken). 
velocity. In this study the P-wave velocity parameter was determined using a Portable Ultrasonic Nondestructive Digital Indicating Tester (PUNDIT) (28-30). The direct transmission method was used. This device has one transmitter and one receiver which are $50 \mathrm{~mm}$ in diameter and have a maximum resonant frequency of $54 \mathrm{kHz}$. The $\mathrm{P}$-wave velocity was measured on dry core specimens and the average of five measurements was considered.

The Schmidt hammer rebound test was applied on NX size core samples as recommended by ISRM (25). The tests were performed with an L-type hammer with the impact energy of $0.735 \mathrm{Nm}$. Five core samples from each rock tested were used and 20 readings were taken for each core specimen. In order to avoid material deflecting the L-type Schmidt hammer, a cradle was used. The Schmidt hammer rebound value was calculated by averaging all of the rebound numbers for each rock sample.

Another hardness test was performed using a D-type Equotip-3 hardness non-destructive tester device. For each NX-size sample, a total of 10 Equotip rebound values were taken, five on each loading surface of the sample; the average of the 10 readings was expressed as the hardness number of Hardness Leep D-type (HLD).

\section{RESULTS AND DISCUSSION}

The petrographic name, mineral composition, texture and matrix of each thin section were summarized (Figure 2). According to Schmidt's classification (31), the samples coded as TI, TII, TIII, TIV and TV were named as vitric ash tuff and BVI was classed as olivine basalt. Almost all the vitric ash tuff samples contain the same minerals, such as plagioclase, pyroxene and opaque minerals, and the crystal rate ranges between $5 \%$ and $30 \%$. However, the vitric content of the tuff samples ranges between $60 \%$ and $95 \%$. The matrix of the tuff samples denoted as TI, TII and TV consists wholly of silicified pumice and rock fragments, whereas TIII and TIV consist of wholly silicified pumice and abundant voids. Except for TI and TII, iron oxidation has occurred in the tuff samples. All the tuff samples have vitrofiric porphyric texture.

The results of the rock mechanical experiments performed to determine some 14 rock properties are summarized in Table 1. As can be seen from the table the range of test scores is quite large due to the test results for the basalt specimens. Based on the strength properties of the tuffs, these rocks have been categorized as "very low strength rocks" in Deer and Miller's (32) classification and as "low strength" in the ISRM (33) description. Some of the test results were also compared with national and international construction stone materials standards (34-41) and the results are summarized in Table 2. Because the porosity of tuff stones is very high and the intergranular bond is weak, they do not satisfy the requirements of the relevant standard $(34,35)$. While the values of both pink and yellow tuff stones are insufficient for use as construction material, only the basalt strength values meet the required values in the standards. Though the tuffs failed to satisfy technical requirements to be utilized as construction materials, they have been commonly used as construction stones in lowstoried buildings and for decorative purposes in the region. It is therefore understood that there is a strong and urgent need to develop and implement a new norm for building stones of volcanic origin. The rock properties given in Table 1 were utilized to describe any likely statistical relationships between them. In particular, there are simple regression relations between some of the mechanical properties of the volcanic stones and also meaningful correlations have been found between thermal conductivity and some non-destructive measurements such as Pundit, Equotip and Schmidt hardness values. The relationship between two value sequences can be established by the coefficient of determination $\left(\mathrm{R}^{2}\right)$. This value, ranging from 0 to 1 , must be high if the curve is to be representative of the relationship between variables (42).

Clear and distinct relationships between UCS and some rock mechanical parameters such as flexural strength, modulus of elasticity, porosity, dry unit weight, water absorption by weight, point load index, wetting-drying loss and thermal conductivity are shown in Figure 3. As shown in the figure, there is a highly correlated polynomial relationship between flexural strength, dry unit weight and UCS, and a highly correlated exponential relationship between modulus of elasticity and UCS. The modulus of elasticity, UCS and density are the dominant parameters in the durability of the stones.

There are strong relationships among them. The mathematical equations of these relations are given as [1], [2] and [3] in the following;

$$
\begin{aligned}
\mathrm{UCS}= & 1.2223(\mathrm{FS})^{2}-0.9937(\mathrm{FS})+ \\
& 20.107 \quad(\mathrm{R}=0.9974) \\
\mathrm{UCS}= & 0.7636(\gamma)^{2}-0.18949(\gamma)+ \\
& 134.09 \quad(\mathrm{R}=0.9889) \\
\mathrm{UCS}= & 14.281 \mathrm{e}^{0.2087 E} \quad(\mathrm{R}=0.9884)
\end{aligned}
$$

where UCS is the unconfined compressive strength in $\mathrm{MPa}, \mathrm{FS}$ is the flexural strength in $\mathrm{MPa}$ and $E$ is the modulus of elasticity in MPa. The empirical relationships proposed can also be satisfactorily used in the early stage of stone durability and valuation.

The correlations between some non-destructive measurement values such as Pundit, Equotip and Schmidt hardness and some rock mechanical 


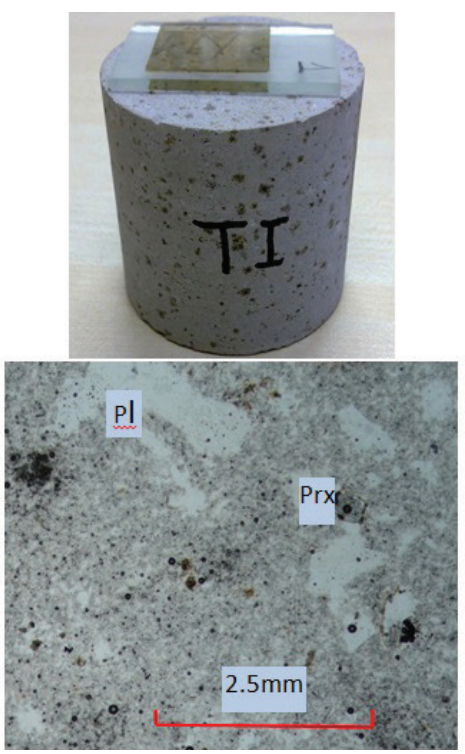

TI: VITRIC ASH TUFF

Composition: $\mathrm{Plj}+\mathrm{Prx}(\mathrm{Ojit})+$

Opac mineral

Vitric: $\% 90$

Crystal: $\% 10$

Litic: \%1

Texture: vitrofiric porphyric

Matrix: wholly silisified pumice

and volcanic rock fragments (VRF)

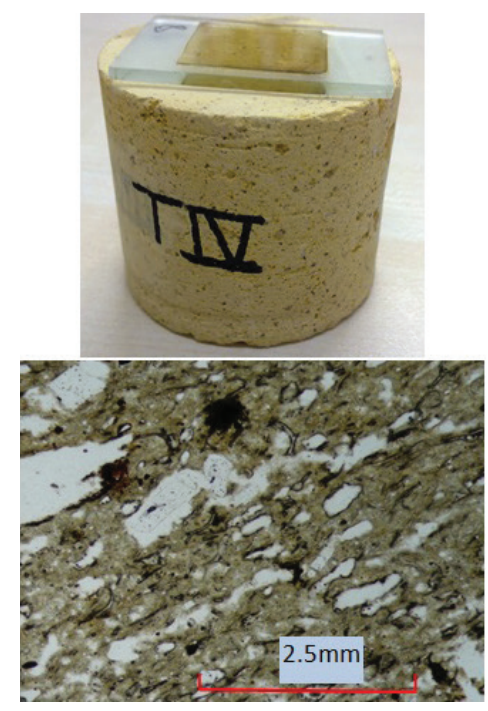

TIV: VITRIC ASH TUFF

Composition: $\mathrm{Plj}+\operatorname{Prx}(\mathrm{Ojit})+$

Opac mineral

Vitric: $\% 90-50$

Crystal: \%5-10

Litic: $<\% 1$

Texture: vitrofiric porphyric

Matrix: wholly silisified pumice

and with abundant void

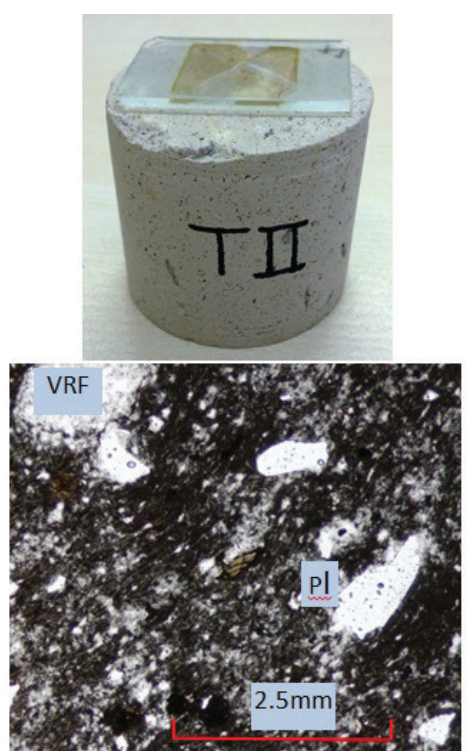

TII: VITRIC ASH TUFF

Composition: $\mathrm{Plj}+\mathrm{Prx}(\mathrm{Ojit})+$

Opac mineral

Vitric: $\% 90$

Crystal: \%10

Litic: $<\% 1$

Texture: vitrofiric porphyric

Matrix: wholly silisified pumice

and volcanic rock fragments

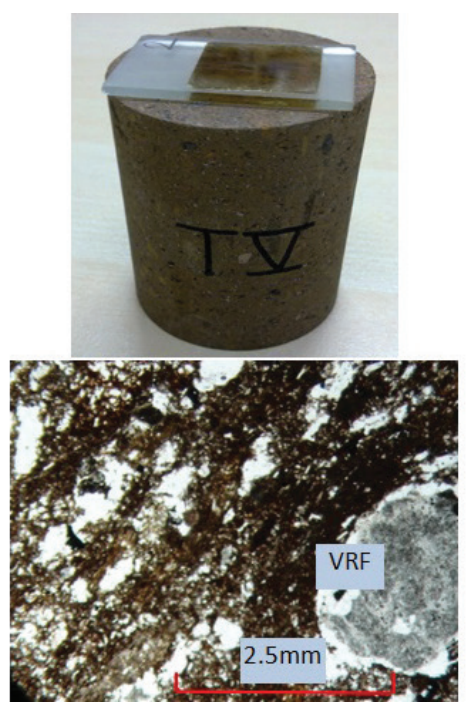

TV: VITRIC ASH TUFF

Composition: $\mathrm{Plj}+\mathrm{Prx}(\mathrm{Ojit})+$

Opac mineral

Vitric: $\% 70$

Crystal: \%20

Litic: \%10

Texture: vitrofiric porphyric

Matrix: wholly silisified pumice

and volcanic rock fragments

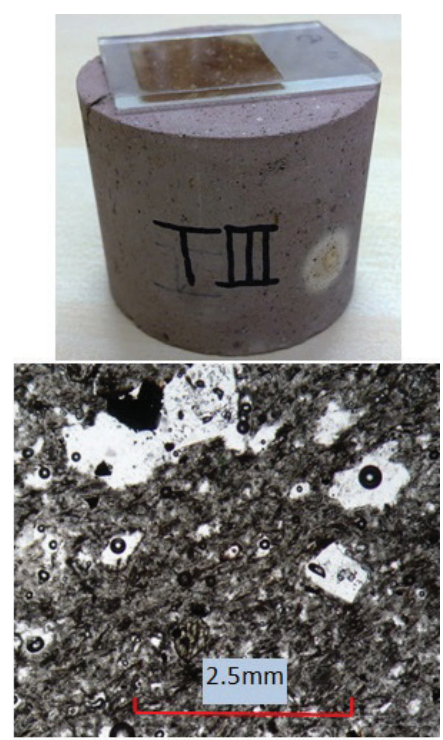

TIII: VITRIC ASH TUFF

Composition: $\mathrm{Plj}+\operatorname{Prx}(\mathrm{Ojit})+$

Opac mineral

Vitric: $\% 60$

Crystal: $\% 30$

Litic: $\% 10$

Texture: vitrofiric porphyric

Matrix: wholly silisified pumice

and with abundant void

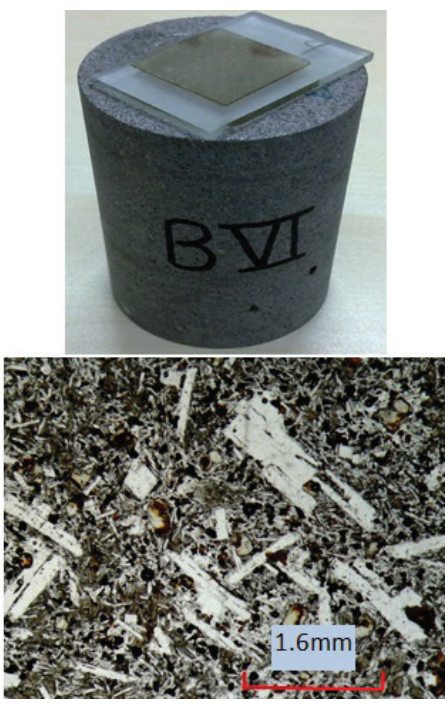

BVI: OLIVINE BASALT

Composition:

$\mathrm{Plj}+$ Olivin(indisited) +

Prx(titanojit) + Opac mineral

Texture: Holocyristaline porphyric

Matrix: plajioklas microlites with

rare void

FIGURE 2. Microscopic views (crossed nicol) of the volcanic building stones 
Mechanical properties of some building stones from volcanic deposits of mount Erciyes (Turkey) 7

TABLE 1. Average values with SD of material properties of volcanic building stones related to Mount Erciyes

\begin{tabular}{|c|c|c|c|c|c|c|}
\hline \multirow[b]{2}{*}{ Rock Properties } & \multicolumn{6}{|c|}{ Rock Type } \\
\hline & $\begin{array}{c}\text { Grey Vitric Ash } \\
\text { Tuff TI } \\
\end{array}$ & $\begin{array}{l}\text { White Vitric } \\
\text { Ash Tuff TII }\end{array}$ & $\begin{array}{l}\text { Pink Vitric Ash } \\
\text { Tuff TIII }\end{array}$ & $\begin{array}{l}\text { Yellow Vitric } \\
\text { Ash Tuff TIV }\end{array}$ & $\begin{array}{l}\text { Brown Vitric } \\
\text { Ash Tuff TV }\end{array}$ & $\begin{array}{c}\text { Black Olivine } \\
\text { Basalt BVI }\end{array}$ \\
\hline Dry Unit Weight kN/m³ & $18.78 \pm 0.10$ & $18.80 \pm 0.39$ & $15.42 \pm 0.1$ & $13.20 \pm 0.11$ & $19.79 \pm 0.19$ & $26.86 \pm 0.23$ \\
\hline $\begin{array}{l}\text { Saturated Unit Weight, } \\
\mathrm{kN} / \mathrm{m}^{3}\end{array}$ & $20.38 \pm 0.07$ & $20.40 \pm 0.16$ & $18.60 \pm 0.04$ & $16.65 \pm 0.13$ & $21.35 \pm 0.11$ & $27.14 \pm 0.15$ \\
\hline Porosity (\%) & $16.37 \pm 0.23$ & $16.43 \pm 0.25$ & $26.72 \pm 0.35$ & $29.47 \pm 0.87$ & $15.96 \pm 0.21$ & $1.83 \pm 0.44$ \\
\hline $\begin{array}{l}\text { Water absorption by } \\
\text { weight }(\%)\end{array}$ & $8.13 \pm 0.44$ & $13.78 \pm 0.54$ & $17.75 \pm 0.38$ & $25.18 \pm 0.49$ & $9.18 \pm 0.35$ & $0.650 \pm 0.01$ \\
\hline P-wave velocity-dry $(\mathrm{m} / \mathrm{s})$ & $1921 \pm 16$ & $2312 \pm 40$ & $1954 \pm 24$ & $1516 \pm 30$ & $2765 \pm 65$ & $4760 \pm 80$ \\
\hline $\begin{array}{l}\text { Thermal conductivity } \\
\text { coefficient }(\mathrm{Wm} / \mathrm{K})\end{array}$ & $0.815 \pm 0.012$ & $0.945 \pm 0.021$ & $0.784 \pm 0.012$ & $0.645 \pm 0.007$ & $0.870 \pm 0.019$ & $1.33 \pm 0.039$ \\
\hline $\begin{array}{l}\text { Equotip hardness value } \\
\text { (HLD) }\end{array}$ & $745 \pm 12$ & $777 \pm 14$ & $560 \pm 11$ & $436 \pm 17$ & $678 \pm 13$ & $844 \pm 9$ \\
\hline Schmidt hardness value & $46 \pm 3$ & $47 \pm 2$ & $34 \pm 6$ & $28 \pm 3$ & $48 \pm 5$ & $55 \pm 3$ \\
\hline Point load index & $5.18 \pm 0.65$ & $5.02 \pm 0.41$ & $2.34 \pm 0.12$ & $1.06 \pm 0.09$ & $2.98 \pm 0.19$ & $21.6 \pm 0.71$ \\
\hline UCS (MPa) & $36.71 \pm 2.25$ & $42.10 \pm 2.01$ & $24.95 \pm 1.67$ & $17.65 \pm 1.02$ & $73.22 \pm 1.87$ & $175.19 \pm 3.10$ \\
\hline Flexural Strength (MPa) & $3.257 \pm 0.20$ & $5.193 \pm 0.45$ & $2.358 \pm 0.15$ & $0.829 \pm 0.069$ & $6.972 \pm 0.365$ & $11.664 \pm 0.852$ \\
\hline $\begin{array}{l}\text { Modulus of Elasticity } \\
(\mathrm{GPa})\end{array}$ & $3.80 \pm 0.31$ & $5.96 \pm 0.39$ & $2.75 \pm 0.18$ & $1.38 \pm 0.12$ & $7.15 \pm 0.0 .63$ & $12.20 \pm 0.49$ \\
\hline $\begin{array}{l}\text { Slake durability } \\
\%\left(\mathrm{I}_{\mathrm{d} 2}\right)\end{array}$ & $98.71 \pm 0.23$ & $99.05 \pm 0.11$ & $98.56 \pm 0.31$ & $87.48 \pm 0.19$ & $99.20 \pm 0.22$ & $99.42 \pm 0.17$ \\
\hline $\begin{array}{l}\text { Wetting and drying lose } \\
\text { after } 80 \text { cycles }(\%)\end{array}$ & $0.14 \pm 0.01$ & $0.13 \pm 0.02$ & $0.56 \pm 0.03$ & $0.85 \pm 0.05$ & $0.10 \pm 0.01$ & $0.04 \pm 0.01$ \\
\hline
\end{tabular}

TABLE 2. Comparison of some test results in terms of the dimension stone standards

\begin{tabular}{|c|c|c|c|c|c|c|}
\hline \multirow[b]{2}{*}{$\begin{array}{l}\text { Rock Properties, Minimum } \\
\text { standard value }\end{array}$} & \multicolumn{6}{|c|}{ Rock Type } \\
\hline & $\begin{array}{l}\text { Grey Vitric } \\
\text { Ash Tuff TI }\end{array}$ & $\begin{array}{l}\text { White Vitric } \\
\text { Ash Tuff TII }\end{array}$ & $\begin{array}{l}\text { Pink Vitric } \\
\text { Ash Tuff TIII }\end{array}$ & $\begin{array}{l}\text { Yellow Vitric } \\
\text { Ash Tuff TIV }\end{array}$ & $\begin{array}{l}\text { Brown Vitric } \\
\text { Ash Tuff TV }\end{array}$ & $\begin{array}{l}\text { Black colored } \\
\text { Olivine Basalt } \\
\text { BVI }\end{array}$ \\
\hline $\begin{array}{l}\text { Dry Unit Weight, } \\
21.19 \mathrm{kN} / \mathrm{m}^{3}\end{array}$ & NS & NS & NS & NS & NS & $S$ \\
\hline $\begin{array}{l}\text { Water absorption by weight, } \\
\% 1.8\end{array}$ & NS & NS & NS & NS & NS & $\mathrm{S}$ \\
\hline $\begin{array}{l}\text { UCS, } \\
35 \mathrm{MPa}\end{array}$ & S & S & NS & NS & S & S \\
\hline $\begin{array}{l}\text { Flexural Strength, } \\
6 \mathrm{MPa}\end{array}$ & NS & NS & NS & NS & S & S \\
\hline
\end{tabular}

NS: Not Satisfactory S: Satisfactory.

properties are shown collectively in Figure 4. There are a number of empirical correlations in the literature regarding the determination of UCS, modulus of elasticity, density, porosity and water absorption and similar rock mechanical properties of stones by simple measurement methods such as P-wave velocity, Schmidt hardness and point load. In this study, Equotip hardness values, which are also simple and fast measuring methods, were mathematically correlated between UCS, dry unit weight, porosity and water absorption by weight of the volcanic stone samples and the relations are expressed in Equations [4], [5], [6], [7], respectively.

$$
\begin{array}{lll}
\mathrm{UCS}=2.3559 \mathrm{e}^{0.0044 H L D} & (\mathrm{R}=0.8106) & {[4]} \\
\gamma=6.8379 \mathrm{e}^{0.0015 H L D} & (\mathrm{R}=0.9188) & {[5]} \\
n=-0.0592(H L D)+57.649 & (\mathrm{R}=0.9147) & {[6]} \\
w=-0.051(H L D)+46.776 & (\mathrm{R}=0.9075) & {[7]}
\end{array}
$$

where UCS is the unconfined compressive strength in $\mathrm{MPa}, \gamma$ is the dry unit weight in $\mathrm{kN} / \mathrm{m}^{3}$, HLD is the Equotip hardness in Leeb-D value, $n$ is the porosity in $\%$ and $w$ is the water absorption by weight in \%. As shown in Equation [4], there is a moderately good relationship between the Equotip 

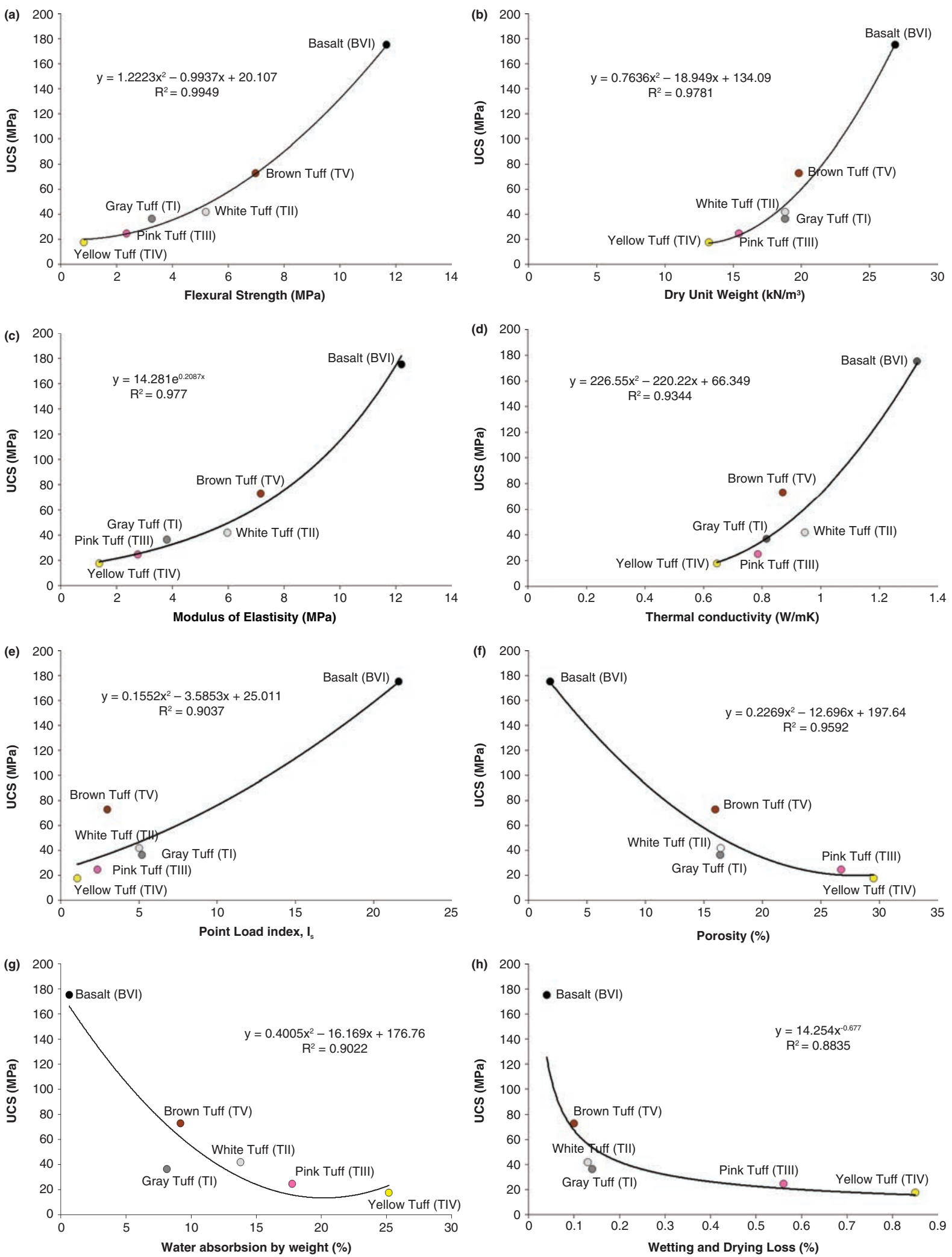

FIGURE 3. Relationship between some mechanical properties and UCS; Variations of UCS with flexural strength in (a), dry unit weight in (b), modulus of elasticity in (c), thermal conductivity in (d), point load index in (e), porosity in (f), water absorption in (g), wetting and drying loss in (h) 
Mechanical properties of some building stones from volcanic deposits of mount Erciyes (Turkey) 9
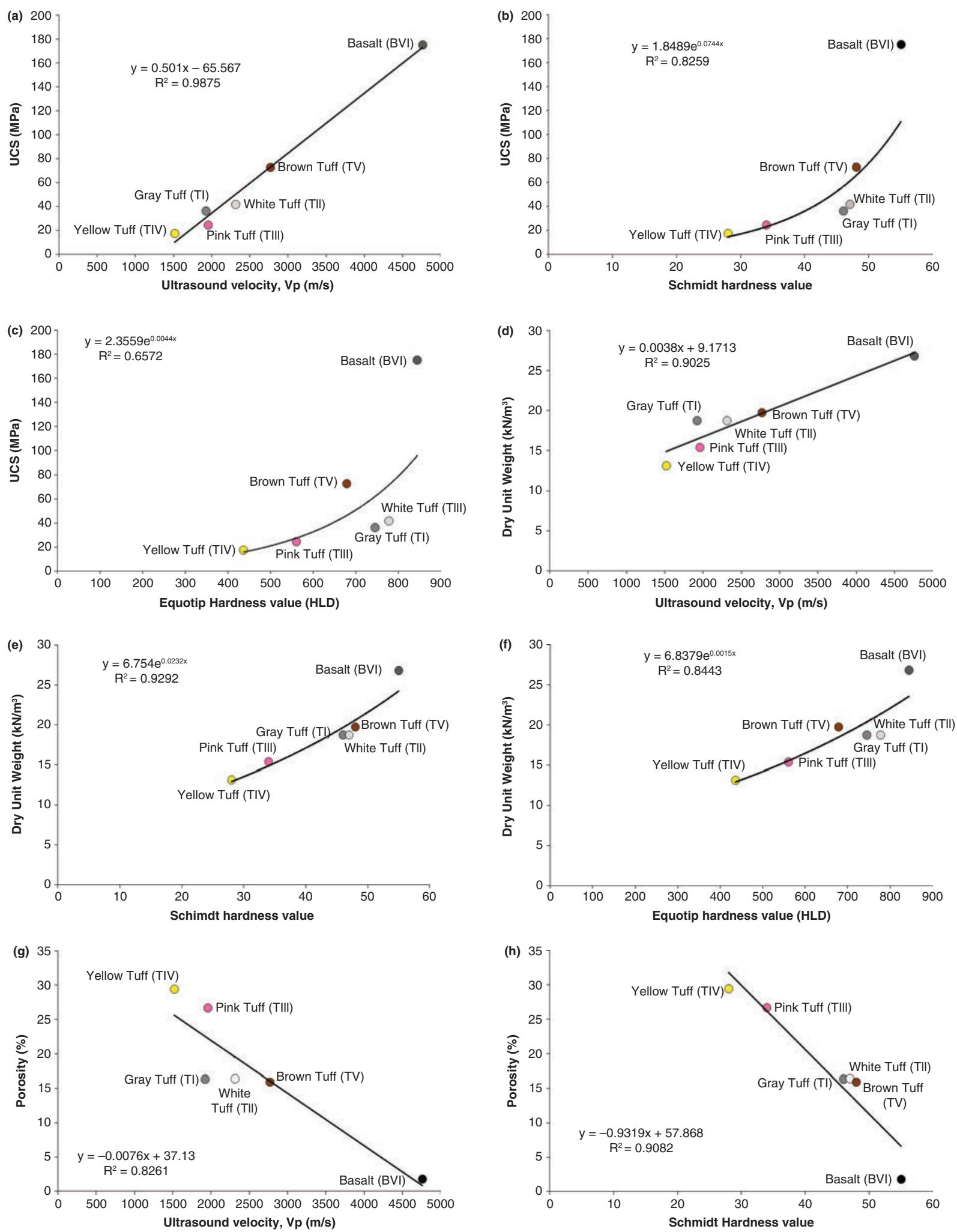

(Figure Continued) 

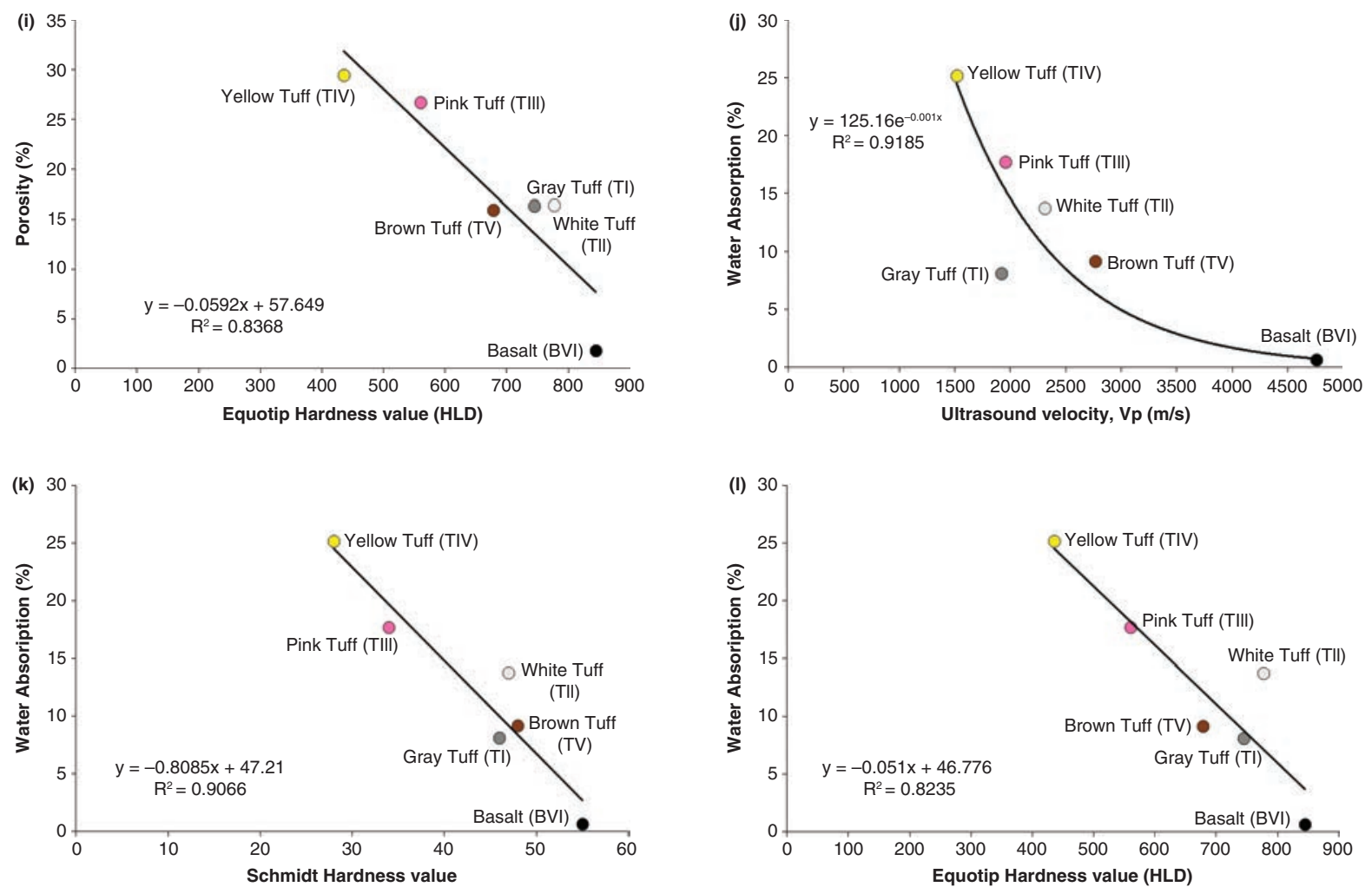

FIGURE 4. Relationship between some NDT measurement values and some mechanical properties; Variations of UCS with P-wave velocity in (a), Schmidt hardness in (b), Equotip hardness in (c); Variations of dry unit weight with P-wave velocity in (d), Schmidt hardness in (e), Equotip hardness in (f); Variations of porosity with P-wave velocity in (g), Schmidt hardness in (h), Equotip hardness in (i); Variations of water absorption with P-wave velocity in (j), Schmidt hardness in (k), Equotip hardness in (l)

hardness HLD value and UCS. On the other hand, there is a fairly good correlation between the Equotip hardness Leeb-D value and the dry unit weight, porosity, and water absorption by weight. There are several studies in the literature on determining the UCS of stones indirectly by the Equotip hardness tester (43-45). In this study, the correlation coefficient derived is higher than that of those derived in previous studies. This may be due to the use of stones of the same origin in this work.

Apart from these, in this study, other relationships are established between some non-destructive measurement values and the thermal conductivities of the volcanic stone samples. The graphs of the P-wave velocity, Schmidt hardness, Equotip hardness, dry and wet dry unit weight, porosity, water absorption by weight and wetting-drying loss versus thermal conductivity are plotted in Figure 5. The most significant relationship seems to be between porosity and thermal conductivity. The thermal conductivity decreases from solid materials towards liquid and gas. For example, the order of conductivity is in the form of air $(0.026 \mathrm{~W} / \mathrm{mK})$, water $(0.613 \mathrm{~W} / \mathrm{mK})$ and ice $(1.88 \mathrm{~W} / \mathrm{mK})(46)$. As the porosities of the volcanic stones increase, the thermal conductivity decreases and there is a polynomial relation with a high correlation coefficient $(\mathrm{R}=0.97)$ between them. In particular, the thermal conductivity of the samples decreased as the porosity of the samples increased, and the yellow tuff with high porosity was the lowest thermal conductivity (Figure $5 \mathrm{f}$ ). So this is because it depends on the physical structure of matter.

Tests to determine the thermal conductivity of stones in steady-state conditions are both laborious and time-consuming. Some non-destructive measurement values such as the P-wave velocity $(\mathrm{Vp})$, Schmidt hardness rebound and Equotip hardness (HLD) can be used to estimate the thermal conductivity. In this work, the following mathematical equations have been derived to easily calculate the thermal conductivity of volcanic stones in [8], [9] and [10].

$$
\begin{aligned}
\lambda= & 0.0002(\mathrm{Vp})+0.4062 \quad \mathrm{R}=0.97 \\
\lambda= & 0.00013(\mathrm{SH})^{2}+0.0906(\mathrm{SH}) \\
& +1.1866 \quad \mathrm{R}=0.94 \\
\lambda= & 0.000005(\mathrm{HLD})^{2}-0.005(\mathrm{HLD}) \\
& +1.9371 \mathrm{R}=0.90
\end{aligned}
$$


Mechanical properties of some building stones from volcanic deposits of mount Erciyes (Turkey) $\bullet 11$
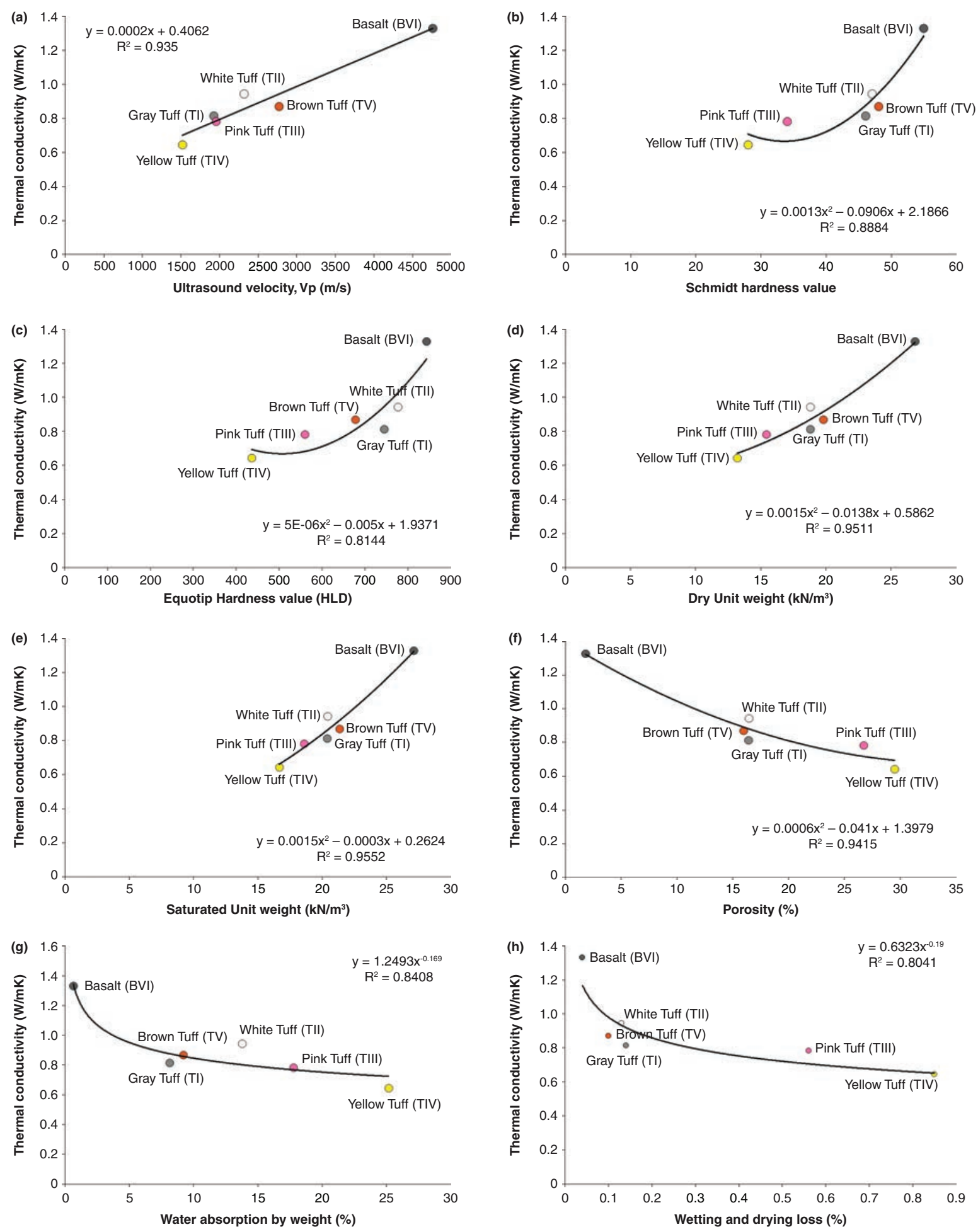

FIGURE 5. Relationship between thermal conductivity and some other mechanical properties; Variations of thermal conductivity with P-wave velocity in (a), Schmidt hardness in (b), Equotip hardness in (c), dry unit weight in (d), saturated unit weight in (e), porosity in (f), water absorption in (g), wetting and drying loss in (h) 
where $\lambda$ is the thermal conductivity coefficient in $\mathrm{W} / \mathrm{mK}, \mathrm{Vp}$ is the P-wave velocity in $\mathrm{m} / \mathrm{s}, \mathrm{SH}$ is the Schmidt hardness value and HLD is the Equotip hardness in Leeb-D value. As shown in Equation [8] above, there is a strong linear relationship between the P-wave velocity and the thermal conductivity. Similarly, as shown in Equations [9] and [10], there is a good relationship between thermal conductivity and Schmidt hardness, Equotip hardness. The empirical relationships given above can be used to determine the thermal conductivity or, in other words, the thermal insulation of the volcanic stone samples.

\section{CONCLUSIONS}

Samples of rocks of volcanic origin from six quarries in Kayseri were tested for their mineralogical characteristics and material properties. Although the rock tuffs are of different colours and brand names, they were all named as vitric ash tuffs in terms of petrographic conventions. The tuffs were characterized by very high porosity, very high water absorption capacity and very low density. However, the thermal conductivity test results show that rock tuffs are advantageous in terms of their low thermal conductivity. When the test results are compared with the standards for construction materials, it is revealed that basalt proves to be adequate for use in structures, cladding facades, flooring, masonry walls, and baseboards. The TI, TII and TV coded stones can be used as cladding facades and low-storied masonry walls, but not for flooring. Due to their low durability, the rock tuffs TIII and TIV are not appropriate to be used for such purposes, but can be used for decorative purposes. Nevertheless, in the light of current practice in the region, it is indicated that new standards for tuffs should be developed so that they can be suggested for possible utilization in construction.

The test results of the rocks were evaluated by regression analyses. Significant relationships between UCS and some rock mechanical parameters such as flexural strength, modulus of elasticity, porosity, dry unit weight, water absorption by weight, point load index, wetting-drying loss and thermal conductivity were developed. The highest correlation was found between UCS and flexural strength, modulus of elasticity and density.

In this work, mathematical relations were also developed to determine the strength of the volcanic rocks indirectly by simple measurement methods. The following equations can be used to indirectly determine some of the properties of the stones, such as UCS, density, porosity and water absorption, using the Equotip hardness device which is not widely used but causes less damage than the Schmidt hammer.

$$
\begin{aligned}
& \mathrm{UCS}=2.3559 \mathrm{e}^{0.0044 H L D} \\
& \gamma=6.8379 \mathrm{e}^{0.0015 H L D} \\
& n=-0.0592(H L D)+57.649 \\
& w=-0.051(H L D)+46.776
\end{aligned}
$$

where UCS is the unconfined compressive strength in $\mathrm{MPa}, \gamma$ is the dry unit weight in $\mathrm{kN} / \mathrm{m}^{3}$, HLD is the Equotip hardness in Leeb-D value, $n$ is the porosity in $\%$ and $w$ is the water absorption by weight in $\%$.

In addition, the thermal properties of volcanic stones can be determined indirectly by means of quick and easy measurement methods. The following mathematical relations have been derived between the thermal conductivity and P-wave velocity, Schmidt and Equotip hardness values.

$$
\begin{aligned}
& \lambda=0.0002(\mathrm{Vp})+0.4062 \\
& \lambda=0.00013(\mathrm{SH})^{2}+0.0906(\mathrm{SH})+1.1866 \\
& \lambda=0.000005(\mathrm{HLD})^{2}-0.005(\mathrm{HLD})+1.9371
\end{aligned}
$$

where $\lambda$ is the thermal conductivity coefficient in $\mathrm{W} / \mathrm{mK}, \mathrm{Vp}$ is the $\mathrm{P}$-wave velocity in $\mathrm{m} / \mathrm{s}, \mathrm{SH}$ is the Schmidt hardness value and HLD is the Equotip hardness in Leep-D value.

The derived equations can be used to predict the durability and thermal conductivity of volcanic rocks.

\section{ACKNOWLEDGEMENT}

I would like to thank the referees for their valuable comments which helped to improve the manuscript. My gratitude is also extended to Prof. Bülent Erdem and Prof. Meftuni Yekeler of Cumhuriyet University who helped in the reorganization of the article.

\section{REFERENCES}

1. Török, Á.; Přikryl, R. (2010) Current methods and future trends in testing, durability analyses and provenance studies of natural stones used in historical monuments, Eng. Geol., 115 139-142. https://doi.org/10.1016/j.enggeo.2010.07.003

2. Selonen, O.; Luodes, H.; Ehlers, C. (2000) Exploration for dimensional stone-implications and examples from the Precambrian of Southern Finland. Eng. Geol, 56, 275-291. https://doi.org/10.1016/S0013-7952(99)00091-5

3. Benavente, D.; Garcia-del-Cura, M.A.; Fort, R.; Ordoñez, S. (2004) Durability estimation of porous building stones from pore structure and strength, Eng. Geol 74: 113-127. https://doi.org/10.1016/j.enggeo.2004.03.005

4. Kahraman, S. (2001a) Evaluation of simple methods for assessing the uniaxial compressive strength of rock. Int $J$ Rock Mech Min Sci 38:981-994. https://doi.org/10.1016/ S1365-1609(01)00039-9

5. Ozkahraman, H.T.; Selver R.; Isik E.C. (2004) Determination of the thermal conductivity of rock from P-wave velocity. Int J Rock Mech Min Sci 41:703-708. https://doi.org/10.1016/j.ijrmms.2004.01.002

6. Çobanoğlu, I.; Çelik, S.B. (2008) Estimation of uniaxial compressive strength from point load strength, Schmidt hardness and P-wave velocity. Bull. Eng. Geol. Environ. 67:491-498. https://doi.org/10.1007/s10064-008-0158-x 
7. Heather Viles, H.; Goudie, A.; Grab, S.; Lalley, J. (2011) The use of the Schmidt Hammer and Equotip for rock hardness assessment in geomorphology and heritage science: a comparative analysis. Earth Surf. Process. Landforms 36, 320-333. https://doi.org/10.1002/esp.2040

8. Fort, R.; Alvarez de Buergo, M.; Perez-Monserrat, E. M. (2013) Non-destructive testing for the assessment of granite decay in heritage structures compared to quarry stone Int. J. Rock Mech. Mining Sci. 61, 296-305. https:// doi.org/10.1016/j.ijrmms.2012.12.048

9. Karakul, H.; Ulusay, R. (2013) Empirical Correlations for Predicting Strength Properties of Rocks from P-Wave Velocity Under Different Degrees of Saturation. Rock Mech Rock Eng 46:981-999. https://doi.org/10.1007/ s00603-012-0353-8

10. Sen, E.; Kürkçüoğlu, B.; Aydar, E.; Gourgaud, A.; Vincent, P. M. (2003) Volcanological evolution of Mount Erciyes stratovolcano and origin of the Valibaba Tepe ignimbrite (Central Anatolia, Turkey) J. Volcan. Geoth. Res.125, 225-246. https://doi.org/10.1016/S0377-0273(03)00110-0

11. Innocenti, F.; Mazzuoli, R.; Pasquaré, G.; Radicati, F.; Villari, L. (1975) Neogene calc-alcaline volcanism of Central Anatolia: geo chronological data on Kayseri-Nigde area. Geol. Mag., 112, 349-360. https://doi.org/10.1017/S0016756800046744

12. Notsu, K.; Fujitani, T.; Ui, T.; Matsuda, J.; Ercan, T. (1995) Geochemical features of collision-related volcanic rocks in Central and Eastern Anatolia, Turkey. J. Volcanol. Geotherm. Res. 64, 171-192. https://doi.org/ 10.1016/0377-0273(94)00077-T

13. Dogan, A. U.; Dogan, M.; Peate, D. W.; Dogruel, Z. (2011) Textural and mineralogical diversity of compositionally homogeneous dacites from the summit of Mt. Erciyes, Central Anatolia, Turkey LITHOS 127: 3-4: 387-400

14. Koprubasi, N.; Guctekin, A.; Celebi, D.; Kirmaci, M.Z. (2014) Mineral chemical constraints on the petrogenesis of mafic and intermediate volcanic rocks from the Erciyes and Hasandag volcanoes, Central Turkey. Chemie der erdegeochemistry 74 (4) 585-600

15. Witte, E. de; Terfve, A.; Koestler, R. J.; Charola, A. E. (1988) Conservation of the Goreme rock: preliminary investigations, Proc. 6th Int. Cong. on Deterioration and Conservation of Stone, Torun: Nicolas Copernicus Univ. 346-353.

16. Topal, T.; Doyuran, V. (1997) Engineering geological properties and durability assessment of the Cappadocian tuff, Eng. Geol, 47: 175-187. https://doi.org/10.1016/ S0013-7952(97)00017-3

17. Aydan, Ö.; Ulusay, R. (2003) Geotechnical and geo environmental characteristics of man-made underground structures in Cappadocia, Turkey. Eng. Geol, 69:245-272. https://doi.org/10.1016/S0013-7952(02)00285-5

18. Ulusay, R.; Gökçeoğlu, C.; Topal, T.; Sönmez, H.; Tuncay, E.; Ergüler, Z.A.; Kasmer, O. (2006) Assessment of environmental and engineering geological problems for the possible re-use of an abandoned rock-hewn settlement in Ürgüp (Cappadocia), Turkey. Envir. Geol, 50, 473-494. https://doi.org/10.1007/s00254-006-0222-4

19. Erdoğan, M. (1986) Nevsehir-Urgüp yöresi tüflerinin malzeme jeolojisi açısından araştırılması (in Turkish). Doctoral Thesis, I.T.U.

20. Korkanç, M. (2007) The effect of geomechanical properties of ignimbrites on their usage as building stone: Nevsehir stone, Geol. Eng.(in Turkish) 31(1): 49-60.

21. Temur, S.; Temur, Y.; Kansun, G. (2007) Geological petrographical and technological investigation of Erkilet basalt, Kayseri, Central Anatolia, Geol. Eng (in Turkish); 31(1): 1-13

22. Yaşar, E.; Tolgay, A.; Teymen, A. (2009) Industrial Usage of Nevsehir-Kayseri (Turkey) Tuff Stone, World Applied Sci. J., 7 (3): 271-284

23. Yüksek, S.; Demirci, A. (2010) Geotechnical properties of volcanic materials of the Mount Erciyes, Volcanic Rock
Mechanics - Olalla et al. (eds), Taylor\&Francis Group, London, ISBN 978-0-415-58478-4, pp 99-105.

24. Özcelik, Y. (2011) Determination of the regions used as facing and building stone according to the material characteristics in an andesite quarry, Eng. Geol, 118: 104-109. https://doi.org/10.1016/j.enggeo.2011.01.005

25. ISRM (2007) The complete ISRM suggested methods for rock characterization, testing and monitoring: 1974-2006. In: Ulusay, R., Hudson, J.A. (Eds.), Suggested Methods Prepared by the ISRM Commission on Testing Methods, Compilation Arranged by the ISRM Turkish National Group. Kozan Ofset, Ankara, 628 pp.

26. TS 699 (1987) Doğal yapı taslarının muayene ve deney metotları (in Turkish). Türk Standartları Enstitüsü, Ankara.

27. ASTM (1990) Standard test method for slake durability of shales and similar weak rocks (D 4644). Annual book of ASTM Standards, Vol. 4.08. ASTM, Philadelphia, PA, $863-865 p$.

28. ASTM C 597-02 (2002) Standard Test Method for Pulse Velocity through Concrete.

29. EN 12504-4, (2003) Testing concrete - Part 4: Determination of ultrasonic pulse velocity.

30. BS 1881-203 (1986) Testing concrete. Recommendations for measurement of velocity of ultrasonic pulses in concrete, British Standards Institution, 26 pages.

31. Schmidt, R. (1981) Descriptive nomenclature and classification of pyroclastic deposits and fragments: Recommendations of the IUGS sub commission on the systematics of igneous Rocks. Geology, 9, 41-43.

32. Deer, D.U.; Miller, R.P. (1966) Engineering Classification and Index Properties for Intact Rock. Technical Report No. AFWL-TR-65-116, Air Force Weapons Laboratory, Kirtland Air Base, New Mexico.

33. ISRM (1981) Basic geotechnical description of rock masses. ISRM Commission on the Classification of Rocks and Rock Masses. Int. J. Rock Mech. Mining Sci. Geom. Abst., $18.85-110$.

34. TS 2513 (1977) Doğal Yapı Taşları, TSE, Ankara.

35. TS 10835, 1993; "Andezit Yapı ve Kaplama Taşı olarak Kullanilan", TSE, Ankara.

36. ASTM C 170, (1990) "Standard Test Method for Compressive Strength of Dimension Stone", Annual Book of ASTM Standards.

37. ASTM C 880, (1989) "Standard Test Method for Flexural Strength of Dimension Stone" Annual Book of ASTM Standards.

38. EN 1469 Natural Stone Products-Slabs for cladding Requirements.

39. EN 12057 Natural Stone Products Modular Tiles Requirements.

40. EN12059 Natural Stone Products - dimensional stonework - Requirements.

41. EN1341 Slabs of Natural Stone for external paving Requirements and test methods.

42. Davis, J.C. (1986) Statistics and Data Analysis in Geology. John Wiley and Sons, New York

43. Verwaal, W.; Mulder, A. (1993) Estimating Rock Strength with the Equotip Hardness Tester. Int. J. Rock Mech. Min. Sci. \& Geomech. Abstr. 30: 659-662. https://doi. org/10.1016/0148-9062(93)91226-9

44. Asef, M.R. (1995) Equotip as an index test for rock strength properties. M.Sc. thesis, ITC Delft University.

45. Anan, S. (1997) Application of rebound hardness test to rock materials. A trial to classify materials by Equotip tests. Proceedings of annual Conference of the Japan society of Engineering Geology Chugoku-Shikoku Branch. $15-18$.

46. Incropera, F.P.; Dewitt, D.P. (1990) Fundamentals of heat and mass transfer. New York: Wiley. 